Egyptian Journal of Aquatic Biology \& Fisheries

Zoology Department, Faculty of Science,

Ain Shams University, Cairo, Egypt.

ISSN $1110-6131$

Vol. 25(2): 591 - 599 (2021)

www.ejabf.journals.ekb.eg

\title{
The intraspecific and spatio-temporal changes in growth pattern and condition factor of Glossogobius aureus inhabiting in the Mekong Delta, Vietnam
}

\section{Gieo Hoang Phan ${ }^{1,2}$, Quang Minh Dinh ${ }^{3 *}$, Ngon Trong Truong ${ }^{4}$, Ton Huu Duc Nguyen ${ }^{3}$, Tien Thi Kieu Nguyen ${ }^{5}$}

1. Biotechnology Research and Development Institute, Can Tho University, Xuan Khanh Ward, Ninh Kieu District, Can Tho 900000, Vietnam

2. Kien Giang University, Minh Luong Town, Chau Thanh District, Kien Giang 920000, Vietnam

3. Department of Biology, School of Education, Can Tho University, Xuan Khanh Ward, Ninh Kieu District, Can Tho 900000, Vietnam

4. Biotechnology Research and Development Institute, Can Tho University, Xuan Khanh Ward, Ninh Kieu District, Can Tho 900000, Vietnam

5. An Khanh High School, An Khanh ward, Ninh Kieu District, Can Tho 900000, Vietnam

*Corresponding Author: dmquang@ctu.edu.vn

ARTICLE INFO

Article History:

Received: Feb. 14, 2021

Accepted: March 30, 2021

Online: April 26, 2021

Keywords:

Condition factor,

Glossogobius aureus,

allometry,

isometry,

Vietnam

\section{ABSTRACT}

The present study was conducted in four sampling sites, from fresh to brackish waters, to contribute knowledge on the length-weight relationship, growth, and body condition factor of the commercial fish Glossogobius aureus (Gobiiformes: Gobiidae) in the Mekong Delta. Fish specimens were caught using gill nets from January to December 2020. Data analyzed results of 742 specimens (382 males and 360 females) showed that weights of males and females in various sizes, seasons, and sites are able to estimate from a fish given length due to high determination coefficients $\left(r^{2}>0.8\right.$, in all cases). The growth pattern of Glossogobius aureus fluctuated monthly from negative allometry to isometry and positive allometry as its slope $(b)$ obtained from $L W R s$ ranged from $2.583 \pm 0.119 \mathrm{SE}$ to $3.123 \pm 0.066 \mathrm{SE}$. Likewise, $b$ of this fish changes with fish size and site, but not season and gender. Albeit the growth pattern showed intraspecific and spatio-temporal variations, this goby displayed negative allometry since $b(2.859 \pm 0.030)$ was lower than three. Likely, fish body condition factors, ranging from $0.937 \pm 0.022 \mathrm{SE}$ to $1.218 \pm 0.030 \mathrm{SE}$, varied between fish sizes, sites, and months. The present findings contributed valuable data to understand fish adaptation and fishery management.

\section{INTRODUCTION}

The fish length-weight relationship $(L W R)$ and the slope coefficient obtained from $L W R$ are essential to evaluate fish stock and growth pattern, respectively (Froese, 1998; Froese, 2006; Dinh et al., 2016a). Condition factor $(C F)$ is used to qualify the variations of fish well-being between species, regions (Abdoli et al., 2009a; Abdoli et al., 2009b), genders, fish sizes, and seasons (Froese, 2006; Dinh et al., 2016b). Glossogobius aureus Akihito and Meguro, 1975 (Gobiiformes: Gobiidae) is one of three commercial species of 
the genus Glossogobius that lives in brackish and freshwaters in Africa, Asia and Oceania regions (Rainboth, 1996; Froese \& Pauly, 2020). This species is a multiple spawner (Nguyen et al., 2014) and displays a negative allometry in $\mathrm{Cu}$ Lao Dung, Soc Trang (Dinh, 2014b), while it shows an isometry in Tran De, Soc Trang; Nha Mat, Bac Lieu; and Ganh Hao, Bac Lieu (Dinh, 2019). In the Mekong Delta, Glossogobius aureus is a target catching fish for food supply (Diep et al., 2014; Dinh et al., 2018), which lessens its natural yield (Dinh et al., 2021). Since this goby is widely distributed in coastal and riverine areas (Dinh, 2009; Tran et al., 2013; Dinh et al., 2018; Nguyen \& Tran, 2018), it is required to quantify whether its length-weight relationship, growth, and body condition factor change with sampling site, gender, fish size and season. The current findings would provide a database to comprehend fish adaptation and fishery management in the studied regions.

\section{MATERIALS AND METHODS}

\section{Study site and fish collection}

The present study lasted for one year (January 2020 to December 2020) from the freshwater region in Cai Rang, Can Tho (CR) to salinization in the dry season in Long Phu, Soc Trang (LP), and brackish water in Hoa Binh, Bac Lieu (HB) and Dam Doi, Ca Mau (DD) (Fig. 1). The semi-diurnal tide represents these places with $\sim 1.2 \mathrm{~m}$ range, 27 ${ }^{\circ} \mathrm{C}$ annual temperature and $\sim 8.0 \mathrm{pH}$. It receives no rain in the dry season (January-May), only substantial showers are observed with $\sim 400 \mathrm{~mm}$ monthly precipitation in the wet season (June-December) (Le et al., 2006; Tran et al., 2020).

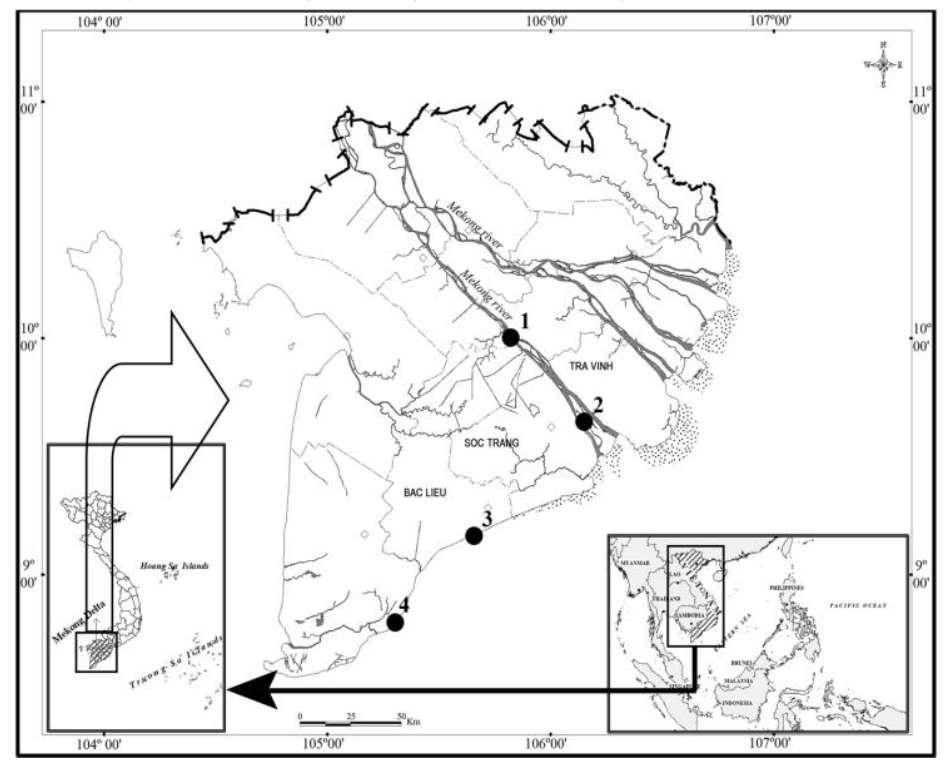

Fig. 1 The map of the sampling sites

Note: Sampling area; 1: Cai Rang, Can Tho; 2: Long Phu, Soc Trang; 3: Hoa Binh, Bac Lieu; 4: Dam Doi, $\mathrm{Ca}$ Mau. This figure was modified from figure 1 produced by Dinh (2018) with permission. 
Fish specimens, according to Dinh et al. (2015), were collected during a period of $48 \mathrm{~h}$ from each study site by using gill nets. Gill nets with $1.5 \mathrm{~cm}$ mesh in the cod end were set at the highest tide and retrieved after 2-3 h. Fish specimens were identified, using the external description given by Akihito and Meguro (1975) before fixation in $5 \%$ formalin buffer, and then were transferred to the laboratory.

\section{Length-weight relationship, growth pattern, and condition factor determination}

Fish specimens were sexed by using genital papilla morphology (triangle for males and oval for females) suggested by Dinh (2014b) before measuring the total length (TL, $0.1 \mathrm{~cm})$ and the body weight $(W, 0.01 \mathrm{~g})$. The length-weight relationship was estimated using the equation: $W=a \times T L^{b}$ ( $W$ is fish weight $(\mathrm{g}), T L$ is fish total length $(\mathrm{cm}), a$ is the regression intercept, and $b$ is the regression slope) (Ricker, 1973). As suggested by Le Cren (1951), the condition factor $(C F)$ was calculated as $C F=W /\left(a \times T L^{b}\right)$ (W: fish weight (g); $T L$ : total length (cm); $a$ : the regression intercept; $b$ : the slope).

\section{Data analysis}

Fish size was divided into immature and mature groups based on the length at first mature of males and females (unpublished data). The determination coefficient $\left(r^{2}\right)$ was used to confirm the quality of the LWRs (Metin et al., 2011). T-test was used to verify if $b$ within gender, fish size, season, month, and site variables were close to the threshold of three (Morey et al., 2003). The variation of $C F$ among months was tested using one-way ANOVA, according to Mahmood et al. (2012). T-test was used to confirm if $C F$ varied within gender, season, and fish size and the significant difference of $C F$ from the favorable conditions of one. All tests were set at $p<0.05$.

\section{RESULTS}

\section{Length-weight relationship and growth pattern}

The data analysis results on LWRs of 742 Glossogobius aureus collected from four sites revealed a close relationship due to $r^{2}>0.850$ in all cases. This goby showed monthly fluctuation as $b$ values obtained from $L W R s(2.583 \pm 0.119$ to $3.123 \pm 0.066 \mathrm{SE})$ varied monthly (Table 1$)$. The $b$ value of males $(2.904 \pm 0.044 \mathrm{SE})$ was similar to that of females $(2.827 \pm 0.040 \mathrm{SE}$, t-test, $p>0.05)$, and this value in the dry season $(2.790 \pm 0.049$ SE) was not significantly different from that in the wet one $(2.914 \pm 0.037 \mathrm{SE}, p>0.05)$ (Table 2$)$. The $b$ values of males, females, dry season, and wet season were lower than the threshold of three $(p<0.05)$ for all cases (Table 2$)$. In contrast, the $b$ value of this goby varied with fish sizes and sites ( $p<0.05$ for two cases), reaching the highest value in $\mathrm{HB}(3.002 \pm 0.059 \mathrm{SE})$ and the lowest in CR $(2.647 \pm 0.076)$ (Table 2). But, in general, the $b$ value $(2.859 \pm 0.030 \mathrm{SE})$ of this goby population was significantly lower than the three $(p<0.05)$. 
Table 1: Length-weight relationship and growth pattern of Glossogobius aureus from four different study sites from January to December 2020

\begin{tabular}{|c|c|c|c|c|c|c|c|c|c|c|c|c|}
\hline \multirow{2}{*}{ Sampling times } & \multicolumn{4}{|c|}{ Number of fish } & \multirow{2}{*}{ Sum } & \multirow{2}{*}{$\frac{b}{\text { Mean } \pm \text { SE }}$} & \multirow{2}{*}{$\begin{array}{l}A \\
\text { Mean } \pm \text { SE }\end{array}$} & \multirow{2}{*}{$r^{2}$} & \multirow{2}{*}{$t_{s}$} & \multirow{2}{*}{$P$} & \multirow{2}{*}{ Growth pattern } & \multirow{2}{*}{$\begin{array}{l}C F \\
\text { Mean } \pm \text { SE }\end{array}$} \\
\hline & $\mathrm{CR}$ & LP & $\mathrm{HB}$ & DD & & & & & & & & \\
\hline Jan-20 & - & - & 18 & 16 & 34 & $2.917 \pm 0.080$ & $0.010 \pm 0.002$ & 0.977 & -1.13 & 0.27 & Isometry & $1.076 \pm 0.014^{\mathrm{c}}$ \\
\hline Feb-20 & 13 & 12 & 19 & 18 & 62 & $2.583 \pm 0.119$ & $0.021 \pm 0.006$ & 0.888 & -3.50 & 0.00 & Negative allometry & $1.006 \pm 0.024^{\text {a.b.c }}$ \\
\hline Mar-20 & 19 & 14 & 12 & 18 & 63 & $2.996 \pm 0.097$ & $0.008 \pm 0.002$ & 0.940 & 0.00 & 1.00 & Isometry & $1.007 \pm 0.017^{\text {a.b.c }}$ \\
\hline Apr-20 & 10 & 15 & 15 & 14 & 54 & $2.697 \pm 0.069$ & $0.016 \pm 0.003$ & 0.967 & -4.57 & 0.00 & Negative allometry & $0.970 \pm 0.017^{\mathrm{a} . \mathrm{b}}$ \\
\hline May-20 & 14 & 15 & 7 & 19 & 55 & $2.550 \pm 0.107$ & $0.022 \pm 0.006$ & 0.915 & -4.09 & 0.00 & Negative allometry & $0.937 \pm 0.022^{\mathrm{a}}$ \\
\hline Jun-20 & 10 & 20 & 13 & 25 & 68 & $2.668 \pm 0.091$ & $0.018 \pm 0.004$ & 0.929 & -3.67 & 0.00 & Negative allometry & $1.076 \pm 0.017^{\mathrm{c}}$ \\
\hline Jul-20 & 14 & 18 & 17 & 23 & 74 & $3.073 \pm 0.123$ & $0.007 \pm 0.002$ & 0.897 & 0.58 & 0.56 & Isometry & $1.050 \pm 0.019^{\text {b.c }}$ \\
\hline Aug-20 & 31 & 16 & 21 & 20 & 88 & $3.034 \pm 0.101$ & $0.008 \pm 0.002$ & 0.913 & 0.30 & 0.76 & Isometry & $1.047 \pm 0.019^{\text {b.c }}$ \\
\hline Sep-20 & 16 & 13 & 20 & 15 & 64 & $3.064 \pm 0.162$ & $0.007 \pm 0.003$ & 0.852 & 0.38 & 0.71 & Isometry & $1.069 \pm 0.024^{\text {b.c }}$ \\
\hline Oct-20 & 10 & 13 & 16 & 16 & 55 & $3.096 \pm 0.109$ & $0.007 \pm 0.002$ & 0.939 & 0.91 & 0.37 & Isometry & $1.071 \pm 0.026^{\text {b.c }}$ \\
\hline Nov-20 & 15 & 14 & 20 & 19 & 68 & $3.123 \pm 0.066$ & $0.006 \pm 0.001$ & 0.971 & 1.71 & 0.09 & Isometry & $1.045 \pm 0.018^{\mathrm{b}, \mathrm{c}}$ \\
\hline Dec-20 & 14 & 15 & 16 & 13 & 58 & $3.086 \pm 0.073$ & $0.008 \pm 0.001$ & 0.969 & 1.29 & 0.20 & Positive allometry & $1.218 \pm 0.030^{\mathrm{d}}$ \\
\hline
\end{tabular}

Note: Different letters (a, b, c and d) in condition factor $(C F)$ category show significant differences $(p<0.05)$. CR: Cai Rang, Can Tho; LP: Long Phu, Soc Trang; HB: Hoa Binh, Bac Lieu; DD: Dam Doi, Ca Mau.

Table 2: Length-weight relationship, growth pattern and condition factor of male and female Glossogobius aureus

\begin{tabular}{|c|c|c|c|c|c|c|c|}
\hline \multirow{2}{*}{\multicolumn{2}{|c|}{ Fish groups }} & \multirow{2}{*}{$\begin{array}{l}\text { Number of } \\
\text { fish }\end{array}$} & \multirow{2}{*}{$\frac{b}{\text { Mean } \pm \mathrm{SE}}$} & \multirow{2}{*}{$\frac{A}{\text { Mean } \pm \text { SE }}$} & \multirow{2}{*}{ Growth pattern } & \multirow{2}{*}{$r^{2}$} & \multirow{2}{*}{$\frac{C F}{\text { Mean } \pm \text { SE }}$} \\
\hline & & & & & & & \\
\hline \multirow{2}{*}{ Gender } & Male & 382 & $2.904 \pm 0.044^{\mathrm{a}}$ & $0.010 \pm 0.001$ & Negative allometry & 0.921 & $1.039 \pm 0.009^{\mathrm{a}}$ \\
\hline & Female & 360 & $2.827 \pm 0.040^{\mathrm{a}}$ & $0.012 \pm 0.001$ & Negative allometry & 0.932 & $1.057 \pm 0.009^{\mathrm{a}}$ \\
\hline \multirow{2}{*}{ Fish size } & Immature & 380 & $3.054 \pm 0.052^{\mathrm{a}}$ & $0.007 \pm 0.001$ & Isometry & 0.902 & $1.038 \pm 0.008^{\mathrm{a}}$ \\
\hline & Mature & 362 & $2.694 \pm 0.053^{\mathrm{b}}$ & $0.017 \pm 0.002$ & Negative allometry & 0.878 & $1.057 \pm 0.010^{\mathrm{b}}$ \\
\hline \multirow{2}{*}{ Season } & Dry & 278 & $2.790 \pm 0.049^{\mathrm{a}}$ & $0.013 \pm 0.002$ & Negative allometry & 0.921 & $1.036 \pm 0.011^{\mathrm{a}}$ \\
\hline & Wet & 464 & $2.914 \pm 0.037^{\mathrm{a}}$ & $0.010 \pm 0.001$ & Negative allometry & 0.931 & $1.054 \pm 0.008^{\mathrm{a}}$ \\
\hline \multirow{4}{*}{ Sites } & Cai Rang, Can Tho & 166 & $2.647 \pm 0.076^{\mathrm{a}}$ & $0.019 \pm 0.004$ & Negative allometry & 0.882 & $1.041 \pm 0.014^{\mathrm{a}, \mathrm{b}}$ \\
\hline & Long Phu, Soc Trang & 165 & $2.824 \pm 0.061^{\mathrm{a}}$ & $0.012 \pm 0.002$ & Negative allometry & 0.929 & $1.033 \pm 0.012^{\mathrm{a}, \mathrm{b}}$ \\
\hline & Hoa Binh, Bac Lieu & 194 & $3.002 \pm 0.059^{\mathrm{b}}$ & $0.008 \pm 0.001$ & Isometry & 0.930 & $1.030 \pm 0.011^{\mathrm{a}}$ \\
\hline & Dam Doi, Ca Mau & 217 & $2.912 \pm 0.059^{\mathrm{b}}$ & $0.010 \pm 0.001$ & Isometry & 0.920 & $1.080 \pm 0.014^{\mathrm{b}}$ \\
\hline
\end{tabular}

Note: Different letters (a and b) in each category (gender, fish size, season, and study area) show significant differences $(p<0.05)$. 


\section{Condition factor}

The $C F$ of Glossogobius aureus varied with months (ANOVA, $F=9.262, \mathrm{p}<0.05$ ), reaching the lowest value in May $(0.937 \pm 0.022 \mathrm{SE})$ and the highest in December $(1.218 \pm 0.030 \mathrm{SE}$ ) (Table 1). Though the $C F$ did not change with genders and seasons, a change was detected with seasons and sites. Specifically, $C F$ of females $(1.057 \pm 0.009$ $\mathrm{SE})$ was similar to males $(1.039 \pm 0.009 \mathrm{SE})$ (t-test, $t=1.339, p>0.05)$, but of the mature fish $(1.057 \pm 0.010 \mathrm{SE})$ it was higher than that of the immature fish $(1.038 \pm 0.008 \mathrm{SE})$ $(t=-1.448, p<0.01)$ (Table 2). In terms of spatio-temporal change, $C F$ of the dry season $(1.036 \pm 0.011 \mathrm{SE})$ was similar to the wet season $(1.054 \pm 0.008 \mathrm{SE})(t=-1.296, p>0.01)$, and this value reached the highest point in DD $(1.080 \pm 0.014 \mathrm{SE})$ and the lowest in LP $(1.033 \pm 0.012 \mathrm{SE}$ ) (one-way ANOVA, $F=3.267, p<0.05)$ (Table 2).

\section{DISCUSSION}

The weights of male and female Glossogobius aureus of different fish sizes, seasons, and sites were directly estimated from a given length as the determination coefficients $\left(r^{2}\right)$ obtained from $L W R s$ were high. It coincides with the previous finding on Glossogobius aureus caught $\mathrm{Cu}$ Lao Dung, Soc Trang (Dinh, 2014b), Tran De, Soc Trang; Nha Mat, Bac Lieu; and Ganh Hao, Bac Lieu (Dinh, 2019). This result in species is similar to many other fish species such as Trypauchen vagina (Dinh, 2016b), Boleophthalmus boddarti (Dinh, 2014a), Glossogobius giuris (Dinh and Ly, 2014), Pseudapocryptes elongatus (Tran, 2008). Besides, this positive correlation was found in Neogobius melanostomus caught from Southern Lake Michigan, USA $\left(r^{2}>0.9\right)$ (Duemler et al., 2016) and Neogobius melanostomus, Neogobius fluviatilis, and Babka gymnotrachelus caught from the Danube river in Serbia $\left(r^{2}>0.8\right)$ (Krpo-Ćetković et al., 2018).

This fish species recorded a higher growth rate in the dry season, suggesting that this fish adapted well to the saltiness of the environment. Glossogobius aureus in the present study belonged to a negative allometric growth pattern $(b<3)$, showing that fish had an advantageous development length compared to its weight, which was also found in the previous study in Cu Lao Dung, Soc Trang (Dinh, 2014b). On the contrary, the growth pattern was isometry in Tran De, Soc Trang; Nha Mat, Bac Lieu, and Ganh Hao, Bac Lieu (Dinh, 2019). This assumption indicated that fish growth pattern related to the environmental condition, which was found in Periophthalmodon schlosseri as it showed a negative allometry growth in Bangladesand (Zhang et al., 2003) but isometry in the Mekong Delta (Dinh, 2016a). Females were often larger than males because the female was usually in fatness and gonadal development to optimize reproductive capability (Le Cren, 1951). However, in Glossogobius aureus, the difference in $b$ value between females and males was not statistically significant, suggesting that both females and males had the role of developing the body to prepare for reproduction. Likely, this goby's growth pattern in the previous study was not regulated by gender (Dinh, 2019). This 
species could adapt well to saltwater regions than in the other places, as it showed isometry in $\mathrm{HB}$ and DD but a negative allometry in CR and LP, whereas in the previous study this goby did not show spatial variation (Dinh, 2019). Some other gobies also exhibited a positive allometric growth pattern, such as rock goby Gobius paganellus in Portugal (Azevedo \& Simas, 2000); Periophthalmus argentilineatus and Periophthalmus spilotus (Khaironizam \& Norma-Rashid, 2002); and in mature Trypauchen vagina in Mekong Delta of Southern Vietnam (Dinh, 2016b).

Unlike the study of Dinh (2019), the $C F$ of Glossogobius aureus, in the present study, was not regulated gonadal developmental stage. The current result coincides with that found in Periophthalmus barbarus (King and Udo, 1998; Chukwu and Deekae, 2011) and Stigmatogobius pleurostigma (Dinh, 2017). However, it was not found in Parapocryptes serperaster (Dinh et al., 2016a). Glossogobius aureus was also regulated by fish developmental stage due to the difference in $C F$ between immature and mature fish, coinciding with the study of Dinh (2019). In contrast, Periophthalmodon schlosseri (Dinh, 2016a) and $T$. vagina (Dinh, 2016b) distributing in the Mekong Delta did not vary with fish sizes. Glossogobius aureus' $C F$ changed with months, fish sizes, and study sites; this value was close to the favorable environment, suggesting that it adapted well to their habitats. This assumption was found in a previous study on this fish species (Dinh, 2019). Moreover, the same supposition was obtained concerning some other gobies: Pseudapocrytpes elongatus (Tran, 2008), Parapocryptes serperaster (Dinh et al., 2016a), Trypauchen vagina (Dinh, 2016b), and Stigmatogobius pleurostigma (Dinh, 2017).

\section{CONCLUSION}

The male and female weights in various sizes, seasons, and sites were estimated from a fish given length due to the high determination coefficients. The growth pattern of Glossogobius aureus fluctuated monthly from negative allometry to isometry and positive allometry, and it changed with fish size and site, but not season and gender. This fish's growth pattern showed intraspecific and spatio-temporal variations, and this species generally displayed a negative allometry. Likely, fish body condition factors varied between fish sizes, sites, and months, but they were close to one. The results were helpful in understanding fish adaptation and fishery management.

\section{ACKNOWLEDGMENT}

This research is funded by the Ministry of Education and Training of Vietnam under grant number B2020-TCT-13. We are grateful to local fishers for sample collection and confirm that fish specimens are performed following the Government's current laws.

\section{REFERENCES}

Abdoli, A.; Allahyari, S.; Kiabi, B. H.; Patimar, R.; Ghelichi, A.; Mostafavi, H.; Aghili, S. M. and Rasooli, P. (2009a). Length-weight relationships for seven gobiid 
fish species in the southeastern Caspian Sea basin, Iran. Journal of Applied Ichthyology, 25(6): 785-786.

Abdoli, L.; Kamrani, E.; Abdoli, A. and Kiabi, B. (2009b). Length-weight relationships for three species of mudskippers (Gobiidae: Oxudercinae) in the coastal areas of the Persian Gulf, Iran. Journal of Applied Ichthyology, 25(2): 236-237.

Akihito, P. and Meguro, K. (1975). Description of a new gobiid fish, Glossogobius aureus, with notes on related species of the genus. Japanese Journal of Ichthyology, 22(3): 127-142.

Azevedo, J. M. N. and Simas, A. M. V. (2000). Age and growth, reproduction and diet of a sublittoral population of the rock goby Gobius paganellus (Teleostei, Gobiidae). Hydrobiologia, 440(1-3): 129-135.

Chukwu, K. and Deekae, S. (2011). Length-weight relationship, condition factor and size composition of Periophthalmus barbarus (Linneaus 1766) in New Calabar River, Nigeria. Agriculture and Biology Journal of North America, 2(7): 1069-1071.

Diep, A. T.; Dinh, Q. M. and Tran, D. D. (2014). Species composition of gobiidae distributed in the coastal areas, Soc Trang Province. VNU Journal of Sciences: Natural Sciences and Technology, 30(3): 68-76.

Dinh, Q. M. (2009). Data of survey on the species composition of fishes in Hau Basin at An Phu district, An Giang province. Can Tho University Journal of Science, 10(213220.

Dinh, Q. M. (2014a). A preliminery study on length-weight relationship of the mudskipper Boleophthalmus boddarti in Soc Trang. Tap chi Sinh hoc, 36(1): 88-92.

Dinh, Q. M. (2014b). Length-weight relationship of golden tank goby Glossogobius aureus Akihito \& Meguro, 1975 in Con Tron River, Soc Trang Province. The 2nd national scientific conference on marine biology and sustainable development. Hai Phong, Vietnam Natural Science and Technology Publisher, pp. 467-472.

Dinh, Q. M. and Ly, T. V. (2014). Preliminary study result of length - weight of tank goby, Glossogobius giuris, distributing in Soc Trang. Can Tho University Journal of Science, 2014(2): 220-225.

Dinh, Q. M.; Nguyen, T. T. G. and Nguyen, T. K. T. (2015). Reproductive biology of the mudskipper Boleophthalmus boddarti in Soc Trang. Tap chi Sinh hoc, 37(3): 362-369.

Dinh, Q. M. (2016a). Growth and body condition variation of the giant mudskipper Periophthalmodon schlosseri in dry and wet seasons. Tap chi Sinh hoc, 38(3): 352358.

Dinh, Q. M. (2016b). Growth pattern and body condition of Trypauchen vagina in the Mekong Delta, Vietnam. The Journal of Animal and Plant Sciences, 26(2): 523-531.

Dinh, Q. M.; Qin, J. G.; Dittmann, S. and Tran, D. D. (2016a). Morphometric variation of Parapocryptes serperaster (Gobiidae) in dry and wet seasons in the Mekong Delta, Vietnam. Ichthyological Research, 63(2): 267-274. 
Dinh, Q. M.; Qin, J. G.; Dittmann, S. and Tran, D. D. (2016b). Reproductive biology of the burrow dwelling goby Parapocryptes serperaster. Ichthyological Research, 63(3): 324-332.

Dinh, Q. M. (2017). Morphometrics and condition factor dynamics of the goby Stigmatogobius pleurostigma (Bleeker 1849) during dry and wet seasons in the Mekong Delta, Vietnam. Asian Fisheries Sciences, 30(1): 17-25.

Dinh, Q. M. (2018). Aspects of reproductive biology of the red goby Trypauchen vagina (Gobiidae) from the Mekong Delta. Journal of Applied Ichthyology, 34(1): 103-110.

Dinh, Q. M.; Tran, D. D.; Vo, T. T.; Nguyen, M. T. and Phan, N. Y. (2018). Study on species composition and some biodiversity indices of gobies distributing in the muddy flat along the coastline in the Mekong Delta. Can Tho Can Tho University, pp. 156.

Dinh, Q. M. (2019). The variation of growth pattern and condition factor of Glossogobius aureus at different fish sizes during dry and wet seasons. Proceeding of The first national conference on Ichthyology in Vietnam. Ha Noi Publishing House of Natural Sciences and Technology, pp. 174-181.

Dinh, Q. M.; Tran, N. Q. and Tran, D. D. (2021). Some biological parameters of Glossogobius aureus population from the Mekong Delta. Iranian Journal of Fisheries Sciences, 20(1): 84-95.

Duemler, J. J.; Kozelichki, J. M. and Simon, T. P. (2016). Relationships between length-weight, age, and body condition of the round goby Neogobius melanostomus (Pallas) in a tributary and harbor embayment in Southern Lake Michigan, USA. Turkish Journal of Fisheries and Aquatic Sciences, 16(1): 205-212.

Froese, R. (1998). Length-weight relationships for 18 less-studied fish species. Journal of Applied Ichthyology, 14(1-2): 117-118.

Froese, R. (2006). Cube law, condition factor and weight-length relationships: history, meta-analysis and recommendations. Journal of Applied Ichthyology, 22(4): 241253.

Froese, R. and Pauly, D. (2020). FishBase. Accessed: 17/01/2021. www.fishbase.org.

Khaironizam, M. Z. and Norma-Rashid, Y. (2002). Length-weight relationship of mudskippers (Gobiidae: Oxudercinae) in the coastal areas of Selangor, Malaysia. Naga, 25(3-4): 20-22.

King, R. P. and Udo, M. T. (1998). Dynamics in the length-weight parameters of the mudskipper Periophthalmus brabarus (Gobiidae), in Imo River estuary, Nigeria. Helgoländer Meeresuntersuchungen, 52(2): 179-186.

Krpo-Ćetković, J.; Prica, M.; Subotić, S.; Nikčević, M. and Mićković, B. (2018). Length-weight relationship and condition of three goby species in the Danube River near Slankamen (Serbia). Geomorphol. Slovac. Bohem, 18(39-45. 
Le Cren, E. (1951). The length-weight relationship and seasonal cycle in gonad weight and condition in the perch (Perca fluviatilis). Journal of Animal Ecology, 20(2): 201219.

Le, T.; Nguyen, M. T.; Nguyen, V. P.; Nguyen, D. C.; Pham, X. H.; Nguyen, T. S.; Hoang, V. C.; Hoang, P. L.; Le, H. and Dao, N. C. (2006). Provinces and City in the Mekong Delta. In: Le, T. (Ed.) Geography of Provinces and Cities in Vietnam. Ha Noi: Education Publishing House, pp. 49-94.

Mahmood, K.; Ayub, Z.; Moazzam, M. and Siddiqui, G. (2012). Length-weight relationship and condition factor of Ilisha melastoma (Clupeiformes: Pristigasteridae) off Pakistan. Pakistan Journal of Zoology, 44(1): 71-77.

Metin, G.; Ilkyaz, A. T.; Soykan, O. and Kinacigil, H. T. (2011). Age, growth and reproduction of four-spotted goby, Deltentosteus quadrimaculatus (Valenciennes, 1837), in İzmir Bay (central Aegean Sea). Turkish Journal of Zoology, 35(5): 711 716.

Morey, G.; Moranta, J.; Massutí, E.; Grau, A.; Linde, M.; Riera, F. and MoralesNin, B. (2003). Weight-length relationships of littoral to lower slope fishes from the western Mediterranean. Fisheries Research, 62(1): 89-96.

Nguyen, M. T.; Huynh, T. N. L.; Nguyen, T. P. and Tran, D. D. (2014). Some reproductive biological characteristics of the Glossogobius aureus Akihito \& Meguro, 1975 distributed in Ben Tre coastal areas. Can Tho University Journal of Science, 2(169-176.

Nguyen, T. M. and Tran, D. D. (2018). Study on feeding habit and feed spectrum of golden tank goby Glossogobius aureus Akihito \& Meguro, 1975. Scientific Journal of Tra Vinh University, 1(29): 64-71.

Rainboth, W. J. (1996). Fishes of the Cambodian Mekong. Roma: FAO, 265.

Ricker, W. E. (1973). Linear regressions in fishery research. Journal of the Fisheries Research Board of Canada, 30(3): 409-434.

Tran, D. D. (2008). Some aspects of biology and population dynamics of the goby Pseudapocryptes elongatus (Cuvier, 1816) in the Mekong Delta. PhD thesis. Universiti Malaysia Terengganu, Malaysia. 186.

Tran, D. D.; Shibukawa, K.; Nguyen, T. P.; Ha, P. H.; Tran, X. L.; Mai, V. H. and Utsugi, K. (2013). Fishes of Mekong Delta, Vietnam. Can Tho: Can Tho University Publisher, 174.

Tran, D. D.; Nguyen, T. V.; To, T. M. H.; Nguyen, T. T. and Dinh, M. Q. (2020). Species composition and biodiversity index of gobiid assemblage in estuarine areas of the Mekong Delta, Vietnam. Egyptian Journal of Aquatic Biology and Fisheries, 24(7): 931-941.

Zhang, J.; Taniguchi, T.; Takita, T. and Ali, A. B. (2003). A study on the epidermal structure of Periophthalmodon and Periophthalmus mudskippers with reference to their terrestrial adaptation. Ichthyological Research, 50(4): 310-317. 